\title{
CALCULATION OF LOADING-INDUCED TENDON SLIP IN BEAMS PRESTRESSED WITH EXTERNAL TENDONS PART I: EXPERIMENT
}

\author{
Bui Khac Diep, Lam Huu Quang \\ Department of Bridge \& Tunnel Engineering, \\ Institute of Transport Science \& Technology
}

\begin{abstract}
This study consists of two parts, in which both experimental and numerical studies on externally prestressed concrete beams were investigated. In Part $I$, three identical beams of $T$ shaped section prestressed with external tendons have been tested to failure to investigate the effects of geometry of the applied load on flexural behavior of externally prestressed concrete beams. The tendon slip at deviators was also monitored in order to examine the evolution of stress in the external tendons. Test results were presented with emphasis on the effects of geometry of applied load and tendon slip at deviators.
\end{abstract}

\section{INTRODUCTION}

Recently, external prestressing is commonly used for construction of new bridges because of its ease and cost saving. However, as the external tendons have no bond with concrete, the deformation of the external tendons is totally different from the deformation in concrete at the tendons level, i.e., the conventional compatibility of deformation between the prestressing tendons and concrete for beams with bonded tendons cannot be directly used to evaluate the stress in the external tendons. Therefore, it is rather difficult to determine the stress in the external tendons under the applied load since it depends on many parameters. Indeed, the stress increase in the external tendons under the applied load, unlike bonded tendons, is member-dependent instead of section-dependent. Thus the stress in the external tendons depends on the deformation of the entire member, and is uniform within the tendon segment between the deviator points. Further more, the stress increase in the external tendons might be likely the same over the entire its length, or be various between the tendon segments since it depends on the extent of frictional resistance at the deviators. Depending on both the loading condition and the extent of frictional resistance, the external tendons can experience three stages of slippage at the deviator points: 1) free slip (free movement); 2) slip with friction; and 3) perfectly fixed (no movement). Therefore, the frictional resistance will have influence in the variation of tendons stress, deflection, as well as the ultimate strength of beams.

Although a large number of studies on the behavior of externally prestressed concrete beams were carried out in the past, most of them did, however, not consider the slip at the deviators. In the experimental study [1 - 6], there were extremely limited research works, which had been examined the slip at deviators, so that very few information on the slip at deviators could be found in the available literature. On the other hand, in the 
numerical analysis there are also limited studies [7 - 12], which were carried out on the slip phenomenon at the deviators since the slippage is often complicated problem, especially for the member-analysis of beams prestressed with external tendons. For the purpose of more understanding, an experimental study with emphasis of the effects of loading arrangement and the tendon slip at deviators on the behavior of externally prestressed concrete beams was performed in Part I of this study. To clearly understand the slip phenomenon at deviators in beams prestressed with external tendons, a computing method for the tendon slip that has been also proposed, will be presented in Part II of this study. The experimental results were discussed, with emphasis on the influence of loading arrangement and slip phenomenon at deviators.

\section{LAYOUT OF EXPERIMENTS}

\subsection{Test specimen and variables}

Three identical beams with T-shaped section were monolithically cast and tested at Department of Civil Engineering, Tokyo Institute of Technology, Japan in 2004 in order to investigate the effects of the geometry of the applied load, the slip phenomenon at deviators on flexural behavior of beams prestressed with external tendons and the stress in the external tendons at ultimate. The test beams have the clear span of $3.0 \mathrm{~m}$ and two deviators located symmetrically from the midspan at distance of $1.5 \mathrm{~m}$ from each other. In all beams, the internal longitudinal reinforcements consisted of two deformed bars of D16 at the bottom and four deformed bars of D6 at the top, with the yielding strength of 365 and $307 \mathrm{MPa}$, respectively. The beams were reinforced with D6 stirrup at interval of $100 \mathrm{~mm}$ in the main part of a beam, and at $50 \mathrm{~mm}$ in the supported regions. The design cylinder strength of the concrete was $55 \mathrm{MPa}$ at 28 days. Beams were prestressed by two 7 -wire strands of SWPR7B $\emptyset 15.2$ type at the same day of loading test. At the prestressing stage, all tendons were stretched from one end by using two hydraulic jacks at the loading level of approximately $50 \%$ of the ultimate strength of tendon. To reduce the frictional effects, the places on the deviators where the external tendons attached to the concrete beams, have an arched shape with the smooth surfaces. In addition, the Teflon sheets were inserted in between the tendons and deviators. The layout of test beams is shown in Fig. 1, and the test variables are summarized in Table 1.

\subsection{Test procedure and measurements}

Each beam was instrumented to measure deflection, concrete strain and bonded steel strain, strain in the external tendons, tendon slip at deviators and crack widths. All strains were measured by using electric resistance strain gages attached to the surface of steel and concrete at desired locations. For the purpose of investigation of the plastic region length, strain gages were attached to the concrete surface at the top fibers at desired points along the beam. Strain gages were also attached to the tensile reinforcements in the constant moment region before casting of concrete at interval of $50 \mathrm{~mm}$ far from each other. To get reliable measurement for the tendon strain during the test, all tendons were monitored. Load cells were placed at the anchorage ends of each tendon to measure the tensile forces in the tendons. In addition, three strain gages were placed on three of seven wires of each tendon segment in order to examine the evolution of the strain in the external tendons. The strain of the tendon segment was taken as an average of three strain gages. For the measurement of crack width, $\pi$-shaped gages were fixed at several locations near by the 
midspan region, where the flexural cracks were expected. For the purpose of investigation of the slip at deviators, extensometers were fixed at each deviator in order to measure the amount of slip during the test. Displacement transducers were placed at the midspan and deviator points to measure the vertical displacement of the beam.

Each beam was simply supported and was loaded monotonically to failure. The plastic region length was investigated by changing the distance between the loading points, from zero for Beam S1 $\left(L_{d}=0\right)$ to third-point loading for Beam $\mathrm{S} 3\left(L_{d}=1.0 \mathrm{~m}\right)$. During the loading, all measurements, such as beam deflection, concrete and steel strains, strain in the external tendons, tendon slip at deviators and crack width were automatically recorded to the data logger. Crack formation, crack spacing and crack growth were also monitored closely by means of visual observations. All cracks that developed during the loading were observed and marked in details.

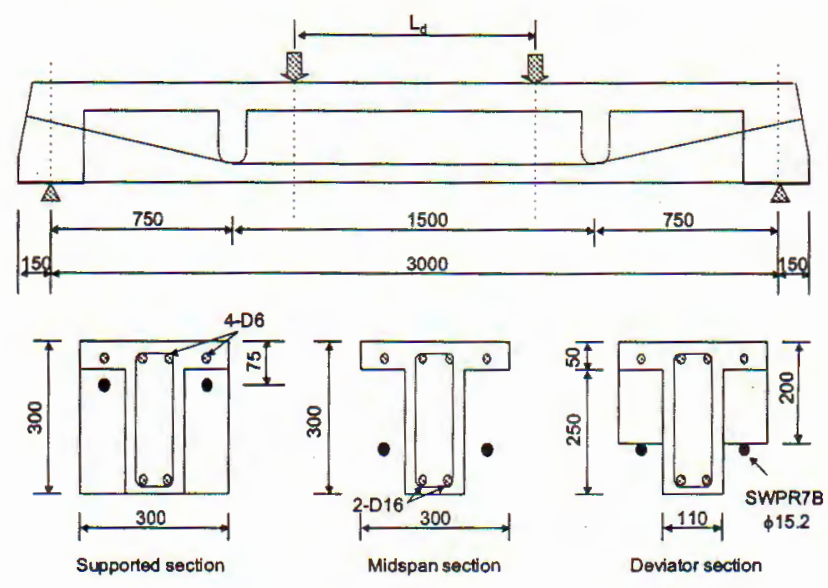

Fig. 1. Layout of test beam

Table 1. Test beam and variables

\begin{tabular}{|l|l|l|l|l|l|l|}
\hline $\begin{array}{l}\text { Beam } \\
\text { No. }\end{array}$ & $\begin{array}{l}L \\
\mathrm{~mm}\end{array}$ & $\begin{array}{l}L_{d} \\
\mathrm{~mm}\end{array}$ & $\begin{array}{l}f_{c}^{\prime} \\
\mathrm{MPa}\end{array}$ & $\begin{array}{l}f_{p e} \\
\mathrm{MPa}\end{array}$ & $\begin{array}{l}\text { Pres. } \\
\text { tendon }\end{array}$ & $\begin{array}{l}\text { Reinf. } \\
\text { bars }\end{array}$ \\
\hline S1 & 3000 & 0 & 61.4 & 956.9 & $\begin{array}{l}\text { SWPR } \\
7 \mathrm{~B}\end{array}$ & $\begin{array}{l}\text { Top } \\
\text { 4-D6 }\end{array}$ \\
\hline S2 & 3000 & 500 & 62.3 & 918.7 & $\begin{array}{l}2-\phi 15.2 \\
\mathrm{~mm}\end{array}$ & $\begin{array}{l}\text { Bottom } \\
\text { 2-D16 }\end{array}$ \\
\hline S3 & 3000 & 1000 & 56.4 & 913.5 & & \\
\hline
\end{tabular}

\section{DISCUSSION OF TEST RESULTS}

\subsection{Beam deflection and tendon stress}

Table 2 summarizes the main results from the test of three beams, while Fig. 2 shows the load-deflection and the load-increase of tendon stress relationships. It is observed from Fig. 2 that during loading history, the relation between load and deflection of all beams showed three distinct stages of behavior, namely un-cracked elastic, cracked elastic and plastic, as schematically shown in Fig. 3. The transition from one stage to others was 
characterized by changing the slope of the curve. The first stage was ended whenever the applied moment was higher than the cracking moment of the beam. In the first stage, the deflection and the stress increase in the tendons was extremely small. Yielding of nonprestressed reinforcements ended the second stage, in which the deflection and the stress increment in the tendons increased, considerably. The third stage was characterized by the significant increase in the beam deflection, as well as the stress in the external tendons with the slight increase in the applied load. Although the beam deflection and the strain in the external tendons increased from the beginning of loading test, the major part of beam deflection and tendon strain, however, were developed mainly in the third stage. The end of third stage was characterized by crushing of concrete at the compressive face, i.e. the concrete reached its limit.

Table 2. Experimental results

\begin{tabular}{|l|l|l|l|l|l|l|l|l|l|l|l|}
\hline \multirow{2}{*}{$\begin{array}{l}\text { Beam } \\
\text { No. }\end{array}$} & \multicolumn{2}{|l|}{\begin{tabular}{l} 
Loading level, $\mathrm{kN}$ \\
\cline { 2 - 11 }
\end{tabular}} & \multicolumn{3}{|l|}{$\begin{array}{l}\text { Tendon stress, } \\
\mathrm{MPa}\end{array}$} & $\begin{array}{l}\text { Ultimate } \\
\text { concrete } \\
\text { strain }\end{array}$ & $\begin{array}{l}\text { Plastic } \\
\text { region } \\
\mathrm{mm}\end{array}$ & $\begin{array}{l}\text { Crack } \\
\text { width* } \\
\mathrm{mm}\end{array}$ & $\begin{array}{l}\text { Slip at } \\
\text { deviator } \\
\mathrm{mm}\end{array}$ & $\begin{array}{l}\text { Ultimate } \\
\text { deflection } \\
\mathrm{mm}\end{array}$ & $\begin{array}{l}\text { Tendon } \\
\text { depth, } \\
\mathrm{mm}\end{array}$ \\
\hline $\mathrm{S} 1$ & 72.1 & 128.3 & 148.2 & 282.9 & 1239.8 & 0.0034 & 467 & 1.98 & $1.36(2.43)$ & 30.3 & 187.3 \\
\hline S2 & 80.9 & 146.8 & 168.4 & 318.4 & 1237.1 & 0.0027 & 476 & 1.42 & $1.68(2.34)$ & 32.8 & 186.4 \\
\hline S3 & 112.3 & 188.6 & 230.1 & 537.6 & 1451.1 & 0.0029 & 1253 & 2.31 & $2.90(4.06)$ & 58.3 & 178.9 \\
\hline
\end{tabular}

* Crack width measured at approximately $90 \%$ of the ultimate load; ** Values in () showed the slip at the right deviator.

Note: Values of beam deflection, stress increase, tendon slip, concrete strain, and tendon depth are taken at the peak load.

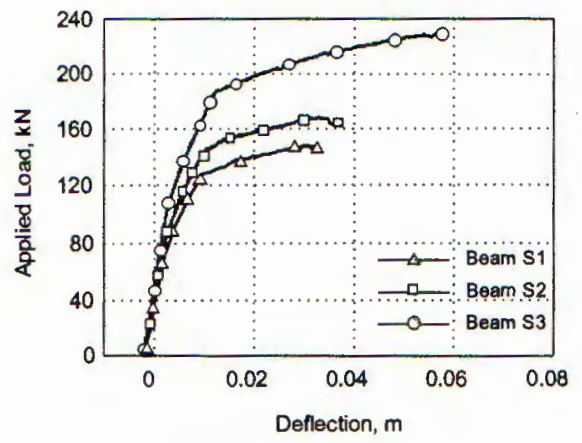

a) Load-deflection responses

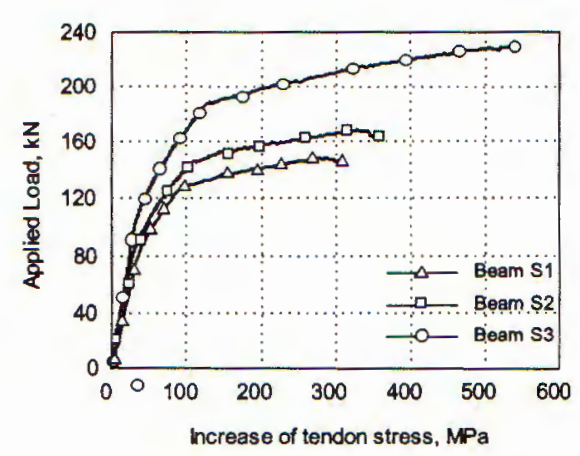

b) Load-increase of tendon stress

Fig. 2. Test results of all beams

It is also indicated in Fig. 2 that the stress increase in tendons is mainly due to the deflection of the beam since the external tendons are attached only to the beam at the anchorages and the deviator points. Therefore, the curve of load-stress increase is very similar to the load-deflection curve through the whole loading range. Before cracking, the stress increase in external tendons showed only slight increase with increasing load. However, after cracking the stress increase tended to increase significantly with the applied load. The rate of stress increase was higher when the applied load passed the yielding limit of non-prestressed reinforcements. Beam S1 with one-point loading at the midspan 
exhibited the minimum load carrying capacity $(148.2 \mathrm{kN})$, while Beam S3 with thirdpoint loading exhibited the maximum load $(230.1 \mathrm{kN})$. Although Beam S2 subjected to two-point loading with distance of $0.5 \mathrm{~m}$ exhibited the load carrying capacity higher than that of Beam S1 (1.13 times), however the ultimate deflection and the increase of tendon stress was not significantly different. This is because the ratio of loading span to span length was considerably small $\left(L_{d} / L=1 / 6\right)$ so that it did not make so much difference compared with Beam S1. Even though the stress increase in tendons of Beam S3 was greatly achieved due to very large deflection, the tendons in Beam S3 did not yield at ultimate, and was far from the yielding strength of the tendons $\left(f_{p y}=1695 \mathrm{MPa}\right)$.

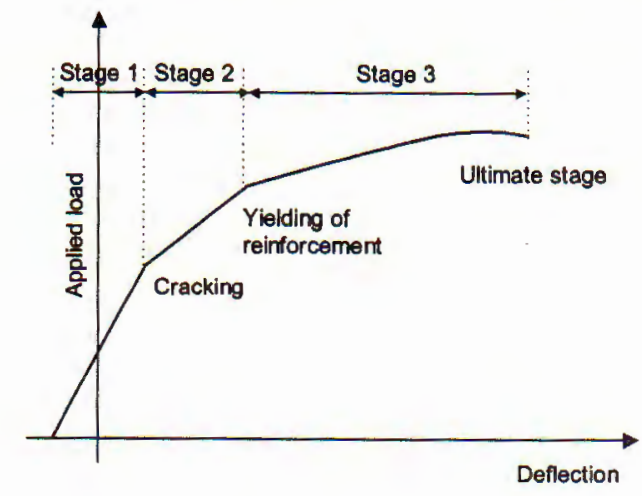

Fig. 3. Simplified load-deflection curve

For the case of study, the change of loading span from zero (a single concentrated load at the midspan) to one-third span length (third-point loading) leaded to the increase in the load carrying capacity of beam of about $55 \%$ and in the stress increase in the external tendons of about $90 \%$. The stresses in the external tendons at ultimate still remained in the elastic range, and were far from the yielding strength of prestressing tendons for all beams. In general, for the case of study the stress in the external tendons at ultimate increased as the loading span increased. As compared with Beam S1, the stress increases in the external tendons in Beams S2 and S3 were about $12 \%$ and $90 \%$ higher as the loading span changed from zero for Beam S1 to $L_{d}=0.5 \mathrm{~m}$ for Beam S2 and $L_{d}=1.0 \mathrm{~m}$ for Beam S3, respectively. The stress in the external tendons of all beams at ultimate varied greatly, from a maximum of 537.6 MPa for Beam S3, down to a minimum of 282.9 MPa for Beam S1.

\subsection{Strain distribution and crack pattern}

The strain distribution of concrete in the extreme compression face at the various loading stage up to failure was presented in Fig. 4. For all beams, the strain distribution of concrete was fairly uniform until the cracking load. After cracking, only compressive strain in concrete at or near by the midspan region increased considerably, especially after the non-prestressed reinforcements had been yielded. At ultimate, the compressive strain in concrete for the beam with a single concentrated loading point was larger than that of beams with two-point loading (see Table 2).

The crack distribution of Beams S1 and S2 was presented in Fig. 5. It can be observed that almost cracks concentrated mainly inside the flexural span, then spread over the region between deviator points as the applied load increased. All cracks in the flexural span were 
almost vertical, while those in the shear span were inclined due to the effect of shear stress. Most of severe cracks occurred at or near by the midspan region, and opened wider as the applied load increased until the ultimate stage.
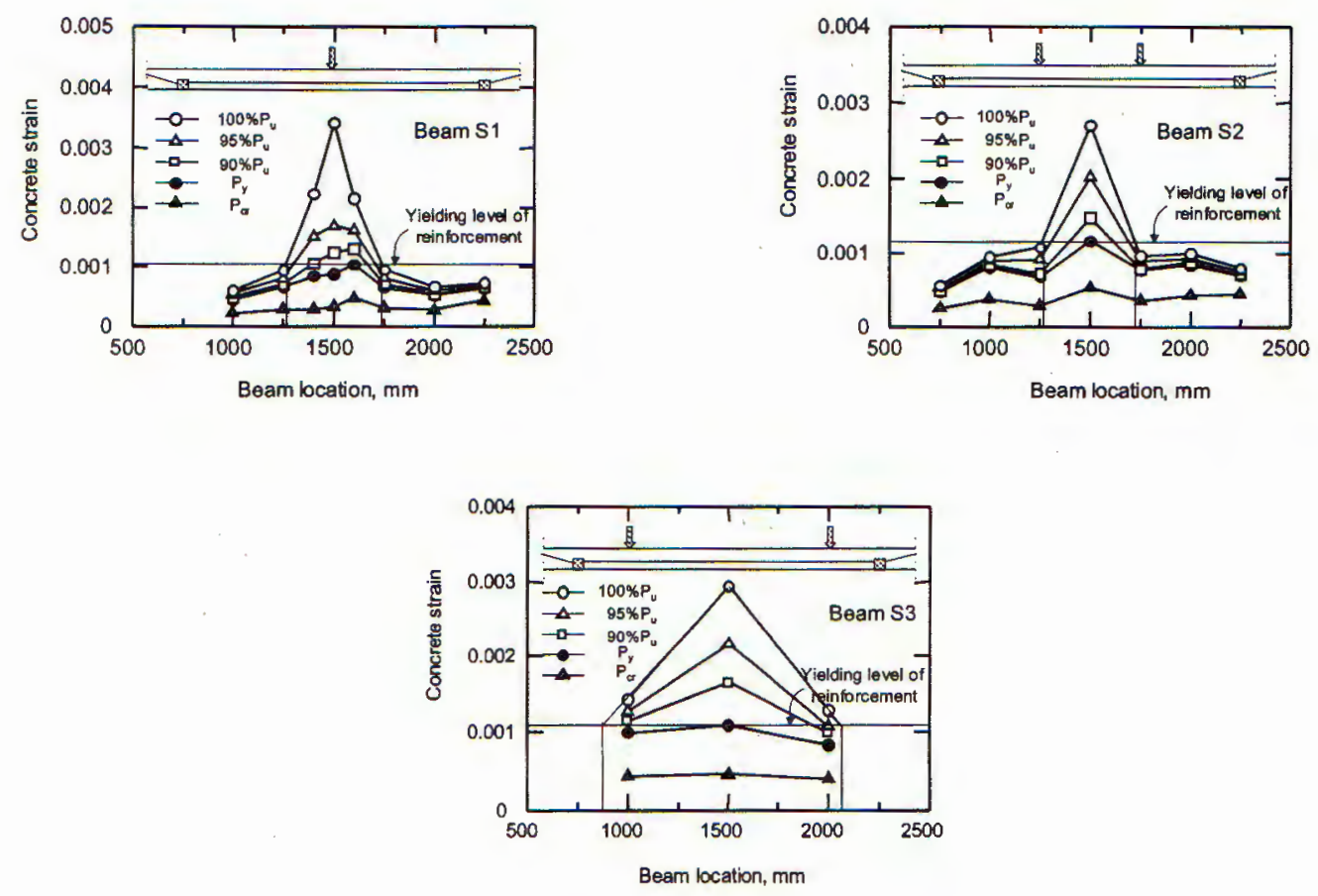

Fig. 4. Distribution of concrete strain

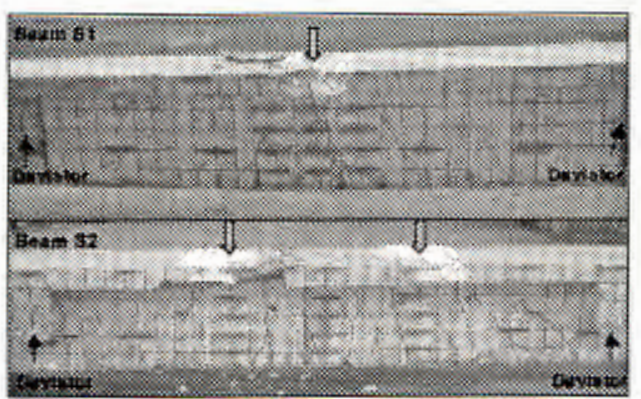

Fig. 5. Crack distribution of Beams S1\& S2

Figure 6 showed the strain distribution of non-prestressed reinforcements at the tensile face. It can be seen that the strain of non-prestressed reinforcements was rather uniform within the zone of constant moment before the yielding load. However, after the yielding load had been passed, cracks at or near by the midspan increased significantly in both length and width. Because of widening of cracks, non-prestressed bonded reinforcements at the crack location were stretched. This resulted by the accelerated increase of tensile strain of non-prestressed reinforcements at the crack locations. It can be clearly seen that the wider crack width is the greater tensile strain of non-prestressed reinforcements at 
that crack location becomes regardless of the crack location (see also Table 2). Further more, as the cracks increased in width and length with the increase in the applied load, the concentration of compressive strain above these cracks was also significantly increased. At ultimate, only few cracks at the midspan opened widely and moved forward to the top flange as shown in Fig. 5.
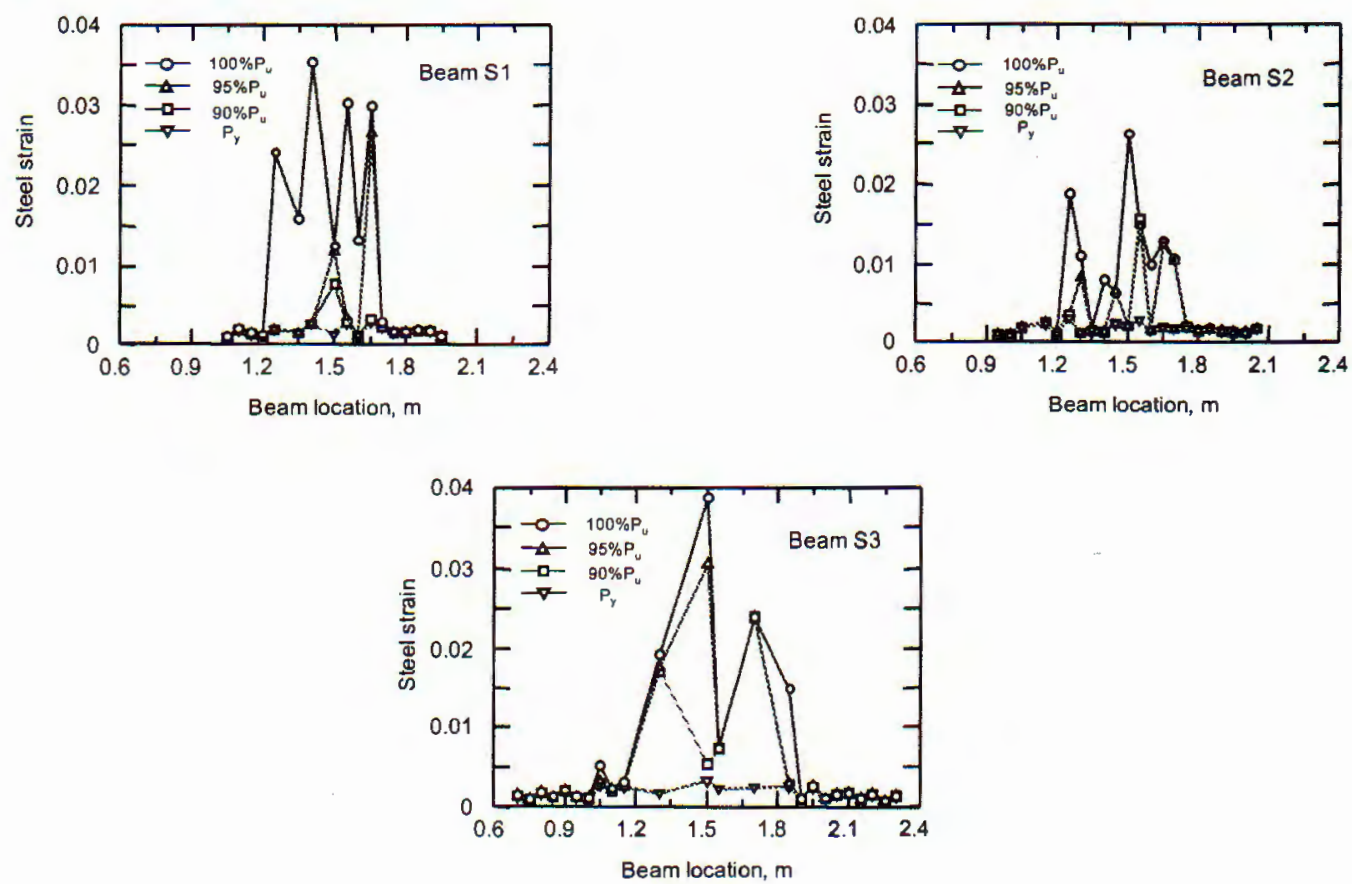

Fig. 6. Strain distributions of non-prestressed reinforcements

\subsection{Plastic region length}

It is experimentally shown that the stress increase in the external tendons depends on the geometry of the applied load, i.e., it depends on the plastic region length that developed in the beams at failure. However, it is extremely difficult to determine "an exact length" of plastic region in the beams at failure. Therefore, it was decided in this study that the plastic region length could be determined from the strain distribution in concrete at the top fibers as shown in Fig. 4. Under the applied load, beams experienced both the elastic and plastic regions. The plastic stage is defined whenever the tensile reinforcements have passed its yielding limit, as mentioned previously. In the other words, the plastic region spreads over the beam length at the level of concrete strain where non-prestressed reinforcements had passed the yielding limit. Therefore, from the strain distribution of concrete in Fig. 4, the plastic region length can be robustly determined, and results were shown in Table 2. It is observed from this table that the stress increase in the external tendons is in direct proportion to the increase in the length of plastic region that developed in the beams at failure. This agreed well with the findings in the previous studies [13]. 


\subsection{Slip at deviators}

Figure 7 presented the relationships of load-tendon slip at the right deviators for all beams. It can be observed that the tendons began to slip, as the applied load reached approximately $50-60 \%$ of ultimate load. The load-tendon slip relationships showed somehow similar to the load-increase of tendon stress curves, i.e., the tendon slip exhibited small increase before yielding of non-prestressed reinforcements, and showed the significant increase with slight increase of the applied load after the yielding strength of non-prestressed reinforcements had been passed. The results from the experimental observation for the tendon slip were also given in Table 2. It is indicated that the tendon slip at ultimate varied with values between $1.36 \mathrm{~mm}$ for Beam S1 and $4.06 \mathrm{~mm}$ for Beam S3. Although all beams have symmetrical arrangement of deviators from the midspan and were subjected to the symmetrical loading condition, however, the amount of tendon slip at both left and right deviators of each beam was found to be different as shown in Beam S2, Fig. 8 . However, the tendon slip at deviators increases in the same tendency with the increase in the applied load.

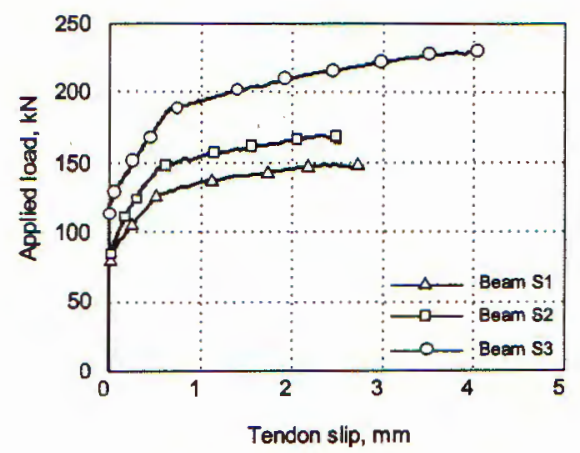

Fig.7. Tendon slip at the right deviator

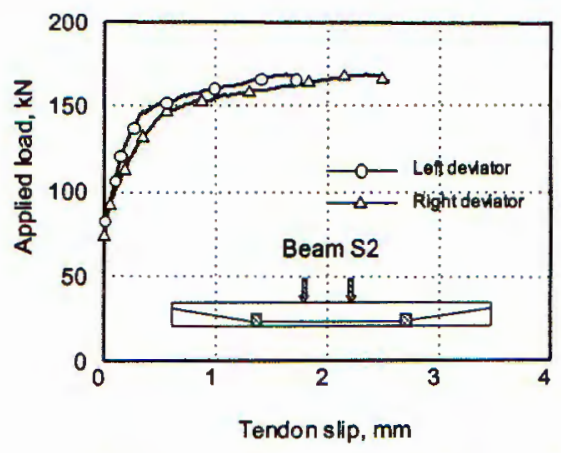

Fig. 8. Tendon slip of Beam S2

Figure 9 showed the evolution of stress increase of each tendon segment of Beam $\mathrm{S} 2$. It is observed from this figure that the development of stress in each tendon segment under the applied load is always different, although the difference in the stress growth seems to be small at the ultimate stage. The difference in development of the tendon stress of each segment was attributed to the frictional resistance, which exists normally at deviators to prevent the strain redistribution between the tendon segments. However, when slip occurred at deviators, the tendon stress was transferred continuously from tendon segment with larger stress to tendon segment with lesser stress through the slippage. Due to the slippage, the frictional resistance at deviators was reduced significantly, as the applied load was close to the ultimate load. As a consequence, the external tendons slip freely on deviators, resulting the external tendons to have approximately the same stress in all tendon segments at ultimate, as shown evidently in Fig. 9. 


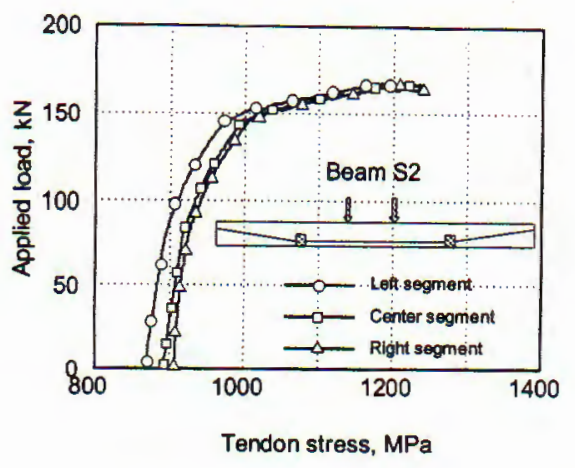

Fig. 9. Evolution of stress in external tendons of Beam S2

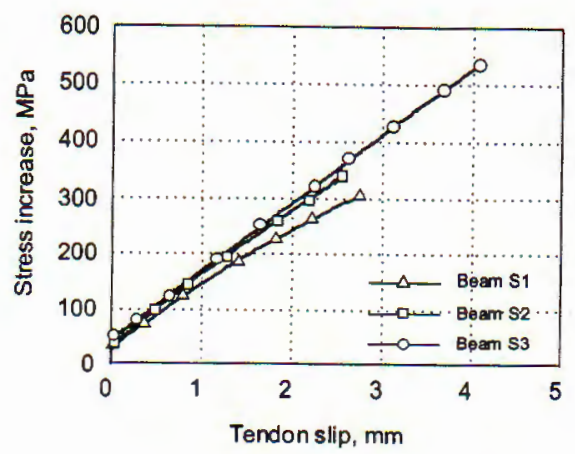

Fig. 10. Stress increase-tendon slip relationship

Figure 10 presented the relationship between the stress increase in the external tendons and the tendon slip at the right deviators for all beams. It can be seen clearly that the stress increase in the external tendons due to the applied load is in a linear proportion with the tendon slip at deviators for all beams. In all cases in this study, the tendon slip did not occur when the stress increase in the external tendons is slightly less than a value of $50 \mathrm{MPa}$. Further, the increasing rate of the tendon stress increment against the slip at deviators in Beams S2 and S3 with two-point loading is slightly higher than those of Beam S1 with one-point loading. In addition, the relationship between the stress increase in the external tendons and the tendon slip at deviators exhibited essentially similar to the curve of the beam deflection-tendon slip relationship as shown in Fig. 11. It is clearly shown that the stress increase in the external tendons due to the applied load has a close relationship not only with the beam deflection, but also with the tendon slip at deviators.

\subsection{Failure mode}

The failure of all beams started by yielding of non-prestressed reinforcements and ended by concrete crushing. After the yielding of non-prestressed reinforcements, the midspan deflection of beams increased very fast with the slight increase in the applied load. Several flexural cracks formed in the zone of constant moment, but only few cracks near the midspan increased significantly in both width and length as the applied load increased. Only the midspan portion or near by it became locally critical zone due to highly concentrated compression strain on the top flange. Before failure occurred, considerable deflection and wide cracks were observed, giving the ample warming of the impending failure. At the moment of failure, the explosive sound appeared and the beam collapsed suddenly by concrete crushing on the compression face. At the same time several pieces of concrete had fell down from one side of the top flange. As a result of falling down of concrete from the top flange, the longitudinal reinforcements in the top flange were exposed with large bucking. This resulted due to the large amount of the prestressing force, which still remained in the external tendons at the failure stage. In addition, a large-width crack was formed in the top flange in the area of concrete crushing. This crack was formed in very high compressive strain in concrete concentrated at the top flange of the midspan region at the failure stage. The failure mechanism of all beams can be explained that as the crack width increased progressively and substantially, the location of neutral axis moved toward the compressive face, simultaneously the compressive strain of concrete reached to 
its ultimate limit and failed in crushing of concrete. Figure 12 showed total collapse of Beam S3 at failure.

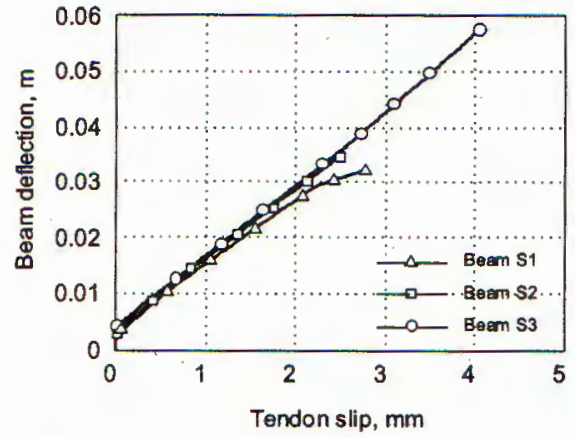

Fig. 11. Deflection-tendon slip relationship

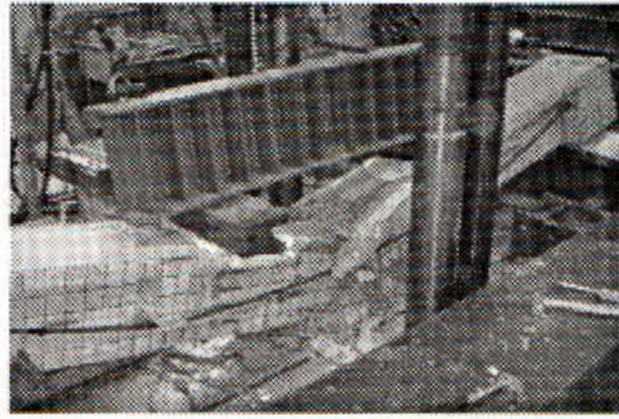

Fig. 12. Failure of Beam S3

\section{CONCLUSIONS}

This study performed the experimental investigation on the behavior of externally prestressed concrete beams with considering the effects of geometry of the applied load and the slip phenomenon at deviators. The following aspects concerning the behavior of externally prestressed concrete beams can be noted:

1. The load carrying capacity and the stress in the external tendons depends strongly on the geometry of the applied load. In general, the increase of loading span leads to the increase in the stress of the external tendons. In in the other words, the stress increase in the external tendons beyond the effective prestress depends mainly on the plastic region length that is expected to develop in the beams at failure.

2. The evolution of tendon stress in all tendon segments is always different because the frictional resistance exists naturally at the contacted points with concrete. The difference in the stress development in all tendon segments under the applied load will diminish as tendons begin to slip due to the redistribution of the tendon stress through the slippage.

3. The tendon slip increases dramatically when the applied load reached closely to the ultimate load. As a consequence, the tendon stress might be fairly uniform in all tendon segments at ultimate.

\section{REFERENCES}

1. H. Mutsuyoshi, K. Tsuchida, S. Matupayont and A. Machida, Flexural behavior and proposal of design equation for flexural strength of externally prestressed concrete members, JSCE Journal of Materials, Concrete Structures and Pavements 26 (508) (1995) 67-77.

2. K. Umezu, M. Fujita, K. Tamaki and J. Yamazaki, Study on ultimate strength of two span continuous beams with external tendon, Proceeding of JCI, 17 (2) (1995) 743-748 (in Japanese).

3. T. Aravinthan, H. Mutsuyoshi, T. Niitsu and A. Chen, Flexural behavior of externally prestressed concrete Beams with large eccentricities, Proceeding of JCI 20 (3) (1998) 673-678. 
4. K. Nishikawa, A. Hiromatsu, M. Suzuki and K. Ito, Study on flexural and shear behavior of externally prestressed concrete beams, Journal of Prestressed Concrete of Japan 42 (5) (2000) 25-36, (in Japanese).

5. E. Witchukreangrai, H. Mustuyohsi, T. Aravinthan and M. Watanabe, Effect of loading arrangement on flexural behavior of externally prestressed beams with large eccentricities, Proceedings of the First International Summer Symposium, JSCE, pp. 287-291, 1999.

6. A. C. Aparicio, G. Ramos and J. R. Casas, Test of externally prestressed concrete beams, Journal of Engineering Structures, Elsevier Science 24 (1) (2002) 73-84.

7. M. Virlogeux, Non-linear analysis of externally prestressed structures, Proceeding of International Symposium in Jerusalem, pp. 309-340, 1988.

8. A. E. Naaman, A New Methodology for the Analysis of Beam Prestressed with External or Unbonded Tendons, External Prestressing in Bridges, ACI, Sp120-16, pp. 339-354, 1990.

9. G. Ramos and A. C. Aparicio, Ultimate analysis of monolithic and segmental externally prestressed concrete bridges, Journal of Bridge Engineering, ASCE 1 (1) (1996) 10-17.

10. M. A. Pisani, A numerical model for externally prestressed beams, Journal of Structural Engineering and Mechanics 4 (2) (1996) 177-190.

11. M. E. Kreger, G. L. Fenves and K. C. El-Habr, Finite Element Analysis of Externally Post-tensioned Segmental Box Girder Construction, External Prestressing in Bridges, ACI, Sp120-19, pp. 389-408, 1990.

12. L. G. Fenves, Nonlinear analysis of externally prestressed bridges, Proceedings of the $9^{\text {th }}$ Conference on Electronic Computation, ASCE, pp.192-201, 1986.

13. M. H. Harajli, Effect of span-depth ratio on the ultimate steel stress in unbonded prestressed concrete members, ACI Structural Journal 87 (3) (1990) 305-312.

Received May 23, 2006

\section{TÍNH TOÁN SỰ TRƯợT CÁP Ở VÁCH CHUYỄN HƯỚNG DƯỚI TÁC DỤNG CƯA TẢI TRỌNG TRONG DẦM BÊ TÔNG CỐT THÉP DỰ ỨNG LỰC NGOÀI PHẦN I: THÍ NGHIỆM}

Công trình nghiên cứu này gồm hai phần, trong đó cả nghiên cứu thí nghiệm và nghiên cứu lý thuyết dầm bê tông dự ứng lực ngoài được khảo sát. Trong phần thứ nhất, ba dầm mặt cắt chữ $\mathrm{T}$ giống nhau được tạo ứng suất trước bằng công nghệ dự ứng lực ngoài, và được thí nghiệm cho đến phá huỷ để khảo sát sự ảnh hường dạng chất tải lên sự làm việc chịu uốn của bê tông dự ứng lực ngoài. Sự trượt cáp tại các vách chuyển hướng cũng được theo dõi để kiểm tra sự biến đổi ứng suất trong cáp. Các kết quà thí nghiệm được trình bày nhấn mạnh đến sự ành hưởng của dạng chất tải và sự trượt cáp tại các vách chuyển hướng. 